\title{
MOTIVATING FACTORS FOR TEACHERS: CASE STUDY
} ANALYSIS

\author{
Ramūnas Vanagas \\ Janina Čižikienė \\ Mykolas Romeris University, Lithuania
}

\begin{abstract}
The article analyses the problem of teachers 'motivation. The continuous change in the teaching process alters the comprehension and principles of teaching substance. Every education organization is unique, having its own culture. Therefore, only the employees" ability to work creatively and innovatively influences the successful work of a school. The requirements of education reform motivate the teachers' and leaders'creativity and initiatives. However, only by solving the means of motivation correctly the teachers will be purposefully involved into the processes of school activity. The applied methods of analysis were analysis of scientific literature and documents, expert interview, analysis and interpretation of the research results. The article presents an overview of scientific literature. In addition, the results of the research may be applied in improving the school activity, motivating teachers for more effective work by considering the satisfaction of employees" needs. The research revealed the essential factors influencing teachers ' motivation in schools.
\end{abstract}

Keywords: motivation, motivation factors, organizational activities, teachers' motivation.

\section{Introduction}

The scientific literature gives considerable attention to work motivation, as this topic receives attention from practitioners and theorists of organization sociology, law and other fields of science. The motivation of employees is widely examined in the USA, Japan, France, Great Britain and others. The problems of employees' motivation were first analysed by scientists (Taylor, 2005, Maslow, 1943, Herzberg, 1987) the works of which were continued by others.

The relevance of the article is determined by the fact that the effect of economic crisis is one of the most severe macro-economic problems as it covers all sectors. With economy slowing down, the number of unemployed increases, organizations find it more difficult to cope with difficulties they face. In a situation of financial crisis, employees in organizations experience emotional stress, which is related to threats to the person's physical security, material welfare, social status etc. All of this very negatively affects the organization's work efficiency as well. During the economic recession, attitude to human resource management competences must change essentially, because under the conditions of crisis they must meet even higher requirements, because problems arise with those problems of personnel management that did not rise otherwise (Užkurèlienė, 2006; Armstrong, 2006, Aužbikavičienè, 2010; Tosi, 2003). 
The main problem discussed by the article may be distinguished, which is being solved both in Lithuania and Western countries - abroad, salary satisfies the primary needs of the majority of the employees, while in Lithuania, salary is insufficient and sometimes does not satisfy even the primary needs (Barkauskaitė, 2001; Matuzienè, 2004; Blaskova,Gražulis, 2009; Diržyteir kt., 2010; Jadzauskaite, 2004). Due to this reason, the motivational system created abroad cannot be fully applied in Lithuania. Thus, the system of employees" motivation must be adapted to the situation in Lithuania and should be applied in organizations' activity.

The scientific literature presents exhaustive theories of motivation, as during the last century, a lot of these were created. The works of both Lithuanian and foreign authors, the review and evaluation of these theories receive considerable attention (Franken, 2002; Greenhaus \& Callanan, 2010; Bučiūnienè, 1996; Marcinkevičiūtè, 2010). The problems and peculiarities of employees' motivation on various aspects were also examined by Kjeldsen, 2012; Atkinson, 1996; Carolyn, 2004; Houston, 2000; Baršauskienè ir kt., 2001, Palidauskaitè, 2007, 2008, Žaptorius, 2007 and others.

However, the lack of researches which would examine the work motivation system and could be successfully applied in assuring the work of particular Lithuanian public sector organizations' employees remains. For the analysis, the authors have chosen a research in one of the subunits of education system schools. Unfortunately, the theoretical material on the research of motivation for particularly this public sector field was insufficient for applying the motivation theories present. Due to this reason, the novelty and relevance of this article is especially visible.

The goal of the article is to analyse the main motivation factors in the work of pedagogues. In order to do so, the authors formulated the following assignments: to find out various scientists ' attitude to the significance of motivation for employees, determine the type of motivation they prioritize and present the conclusions.

The following research methods were invoked: literature analysis, document analysis, comparative method, structured expert interview.

\section{The importance of employees' motivation in an organization}

During the economic crisis, motivation of employees is especially important in Lithuania. When there are no possibilities to increase salary, which is the factor that motivates the employees most, means of motivation that have little or no cost should be considered, which would allow to retain employees, create a good atmosphere in the workplace so that even people that receive modest salary would be satisfied in their work. Therefore, it is beneficial to examine the motivation of every organization employees.

According to Mullins L.J. (2004), Felser G. (2006) and many other authors, one of the most important assumptions of successful leaders' work is the ability 
to use appropriate mechanisms of motivation employees. The importance of motivating employees during the economic recession is distinguished very often. According to Bowditch, J.L., Buono, A.F. (2001) and other authors, the ability to motivate just as the ability to lead is more important nowadays than ever before. As Redman T., Wilkinson A. (2009), Nutt P.C. (1999) and others emphasize, during the crisis, it is mostly important for the organizational leaders to apply reasoned means of motivating employees.

In critical conditions, it is extremely important that the leaders appropriately motivate their employees, show new possibilities and inspire for new challenges. It was ascertained many times that during the economic crisis, production workers are best motivated by material means of motivation: work salary, prizes and bonuses. The most effective non-material means of motivation are career possibilities, work appreciation, improvement of organization's culture and work environment (Higgins, E.T. \& Kruglanski, A.W. (Eds.) (2000), Sims S.J. \& Sims R.R. (2007) and others).

Nowadays, the main assignment given to the employees in every organization is the improvement of efficiency and quality. It is important for the organizations to understand, what motivates the employees to work efficiently. Effective system of motivation in an organization covers the systems of salary and motivation. Speaking of motivation that would stimulate to work well, we are speaking about a plethora of factors that motivate to work. No matter how much the topic of motivation was, is or will be examined, this topic will always remain relevant in order to increase employees' efficiency, because the motivation of employees always changes, thus a universal model of motivation cannot be created and applied for a long time. Motivation is not a continuous state, it must always be supplemented. In order to create a model of motivation that motivates efficiency, the individual needs of every employee should be considered and a system of motivation that would apply to all employees should be created. To do so, the wishes and needs of one's employees must be well known.

When discussing the development of motivation process, V.Gražulis (2005) emphasizes that the centre of attention of early management theories was salary, which meant that the employee was working better for higher pay. During that time, the main leaders' assignment was to ensure the control and quality of work of employees. Later, after the world economic crisis, when the economic situation improved, attention was drawn to other than monetary means of motivation - theories were created which explained that people in an organization form a kind of social system, where not only the money matters, but also acknowledgment, gratitude and attention. The duties of the leader changed as well - during this period, it was the most important to ensure good micro-climate in the organization, create such conditions that the employees would feel needed and important. In the next stage of motivation theories" creation, factors such as creativity, independence, autonomy were considered, 
while the leader's goal was to create conditions that would allow the employee's creativity and abilities to unfold.

\section{Main factors of motivation}

It may be stated that motives can be very different. The majority of motivation specialists seek to find all the identifiable motives and activating means. L. Marcinkevičiūtè (2010) presented a table of employees' motives and motivation means combination (Table 1.)

Table 1. Combinations of motives and motivation means

\begin{tabular}{|c|c|}
\hline Types of motives & Examples of motivation means \\
\hline $\begin{array}{l}\text { Motives of satisfaction of } \\
\text { needs: efficiency, work } \\
\text { in one organization, } \\
\text { work quality }\end{array}$ & $\begin{array}{l}\text { Increase of salary; unitary form of payment for work; constant } \\
\text { bonuses to salary; prizes; material help; participation in } \\
\text { distribution of organization's profit; grant of preferential credit; } \\
\text { cover of medical, transport, sport club expenditures. }\end{array}$ \\
\hline $\begin{array}{l}\text { Motives of life self- } \\
\text { expression: } \\
\text { acknowledgment, self- } \\
\text { expression, interest, } \\
\text { creation works }\end{array}$ & $\begin{array}{l}\text { Granting work according to interests; professional orientation; } \\
\text { non-specialized development of career; increase of work } \\
\text { creativity, grant of possibilities to learn; prizes for innovations, } \\
\text { inventions, ideas, offers; opportunity to use information; grant } \\
\text { of information. }\end{array}$ \\
\hline $\begin{array}{l}\text { Social motives: } \\
\text { solidarity, } \\
\text { communication, security }\end{array}$ & $\begin{array}{l}\text { Ability to communicate at work; correct distribution, evaluation } \\
\text { and motivation of work, duties and responsibilities; democratic } \\
\text { style of leadership; equal opportunities; assurance of security } \\
\text { techniques and work hygiene in the workplace. }\end{array}$ \\
\hline $\begin{array}{l}\text { Motives of status } \\
\text { consolidation: success, } \\
\text { leadership, achievement } \\
\text { of goals, career growth }\end{array}$ & $\begin{array}{l}\text { Appointment to leading work; improvement of work } \\
\text { conditions; parlour, car; participation in making important } \\
\text { decisions; rise through stages of career; representation of } \\
\text { another organization. }\end{array}$ \\
\hline $\begin{array}{l}\text { Motives of work, life } \\
\text { cycle optimization: } \\
\text { social and professional } \\
\text { mobility, overcoming of } \\
\text { status and psychological } \\
\text { discomfort }\end{array}$ & $\begin{array}{l}\text { Distribution of work regarding wishes and abilities; youth care; } \\
\text { work juxtaposition with pedagogic activity psychological } \\
\text { support; open door policy; industrial dispute commission. }\end{array}$ \\
\hline
\end{tabular}

Source: created based on Marcinkevičiūtè (2010)

Considering the scheme presented below (Fig. 1), internal motivation consists of personal satisfaction in work, when a person finds his favourite activity that he finds satisfying. Next form of internal motivation is explained as submission to the accepted standards that make people work, e.g. dedication to group members, standards of ethics that bestow respect. Third form of internal motivation is explained as a boring uninspiring process of carrying out a procedure, the result of which bring sweet fruits later on and provides satisfaction for the person working (Re'em, 2011, p. 6-7). 
According to Palidauskaite J. (2008) the following main factors influencing satisfaction in work are distinguishable: work content, work conditions, augmentation of employees' autonomy, salary, career, leadership, organizational structure and environment, participation in making decisions and social guarantees (p. 10). In addition, Gražulisetal (2012) supplement this list by adding more important work motives mentioned in the scientific literature:

- $\quad$ Satisfaction in work place;

- $\quad$ Realization of social security and means of integration system;

- $\quad$ Opportunity to use a flexible work schedule;

- One's identification with the given assignment;

- Orientation to the improvement of the cost and result ration, determination to take on risks;

- Orientation of behaviour to cooperation and constructive collaboration;

- Realization of social responsibility norms towards co-workers;

- Interest in using the information that the organization needs;

- Opportunity to be informed about the business of the organization;

- Understanding the organizational goals and orientation to future;

- Integration to organization's business, delegation of responsibility and self-control;

- Opportunities of creative and innovative work;

- Conditions for perfection of professional qualification;

- Opportunity to make decisions;

- $\quad$ Professional mobility and favourable conditions for career (p. 124).

Concluding the opinions of various authors, it may be stated that the scientific literature distinguishes various means of motivation, thus, it is important that the classification of these means is provided (Fig. 1).

The works of the majority of Lithuanian scientists confirmed the most important aspects presented in the article by carrying out researches and analyses in other fields of public sector (Rodzevičiūtè, 2007; Palidauskaite, 2007; Diržytè, 2010). 


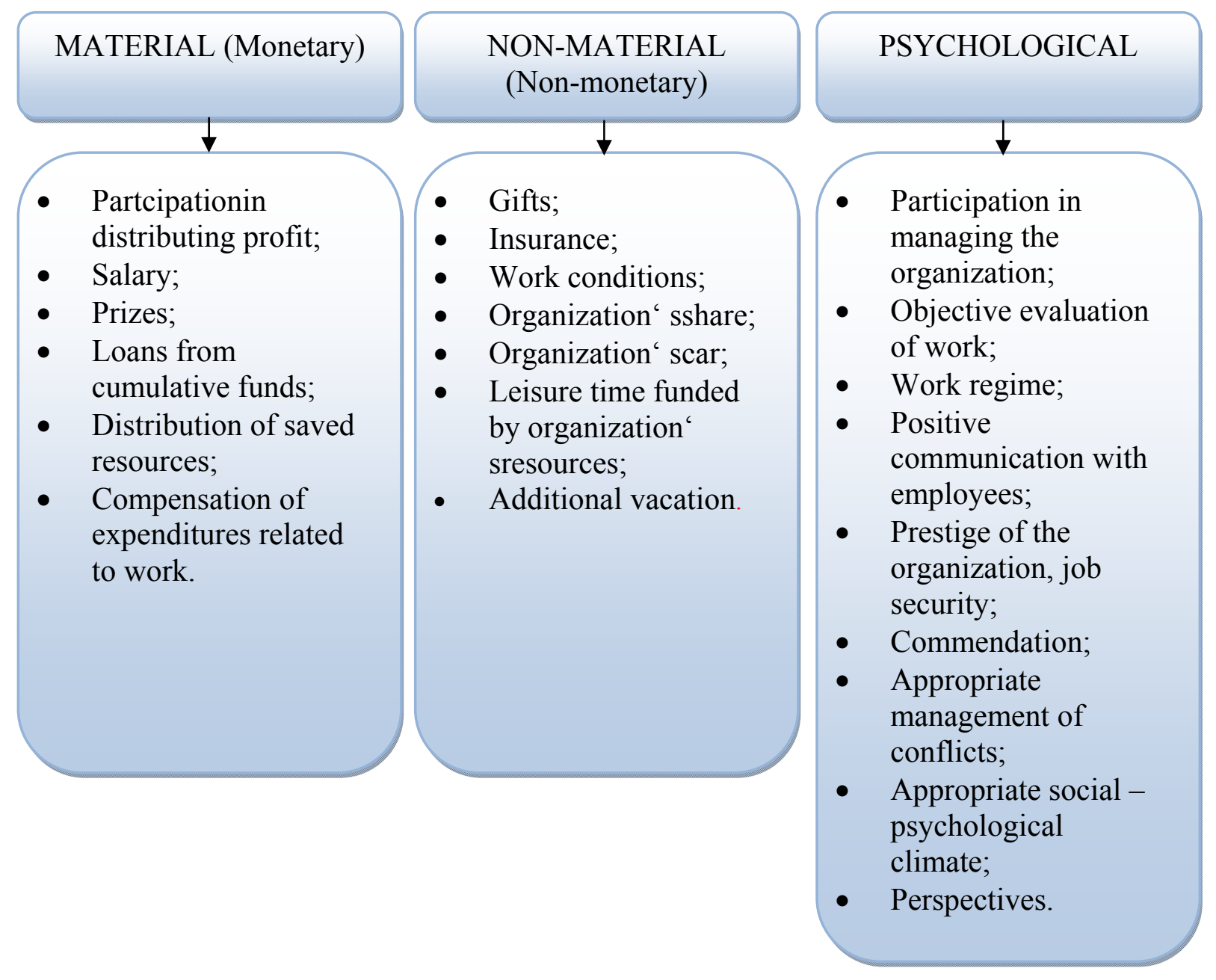

Figure 1. Classification of the means of motivation

Source: L. Marcinkevičiūtè (2010)

With informational technologies becoming wider rapidly, the role of the teacher changes as well, as he must not only convey the knowledge on the subject, but also to help obtain skills of communication and collaboration by broadening one's creativity, discovering and appreciating uniqueness. The teacher must occupy an important place in the process of education, with a creative attitude to effective work, motivation and should always change and seek perfection.

The number of teachers in Lithuania is decreasing. In the school year of 2013-2014 there were 51,000 pedagogues. During the last decade, this number has decreased by almost 18,000 (http://www.stat.gov.lt/). Therefore, working pedagogues must have motivation to work under ever-changing conditions.

Motivation of teachers is one of the education management functions. Attitude to work motivation changes along with interpersonal similarity and interpersonal individuality. According to L. Pakalkaite (2006), the majority of employees begin to work unenthusiastically. However, researchers state that in 6 months after being employed, 85 percent of the employees find their wish to 
work drastically decrease. Often, the leaders are responsible for such loss of motivation. If a pedagogue loses his desire to work, he will also have no motivation in improving his qualification, applying modern education methods in the education process.

T. Lileikiene (2008) distinguished the following types of qualification improvement motivation system: motivation regulated in the school's strategic documents; motivation by creating conditions for improving qualification; motivation by creating a communicative atmosphere, motivating team work; non-material motivation of teachers; evaluation and self-evaluation system in an organization.

\section{Peculiarities of pedagogues' motivation (expert research)}

An interview is one of the effective methods of qualitative research. This method was invoked because the information is obtained through direct, focused interview with the respondent. The direction and content of the interview is influenced by the problem of the research. During an unstructured interview, 8 leaders were questioned. Two criteria for selection of informants were chosen: direct leadership in an institution (one must be a director) and a striving to improve professional qualification (managerial category). The informants were introduced with the goal and use of the research. Also, the questions of confidentiality were discussed. During an interview, the obtained data were analysed using the qualitative content analysis method.

It was determined, that a motivated teacher is ",benevolent ", ,innovative“, „communicating and collaborating“, ,seeks for the highest evaluations in his work", , is able to effectively plan his work", ,invokes motivation to learn ". It is interesting to note that being ,proud of the chosen profession "was also distinguished.

It should be noted that motivation is an extremely important factor in order to coordinate the personal and organizational goals: , good school results have influence on the teacher's success and acknowledgement”, "teacher's expectations and needs have to be considered”, ,atmosphere favourable for work is created when teachers are motivated appropriately”, ,motivation is one of the factors for successful work of school as an organization".

Experts who participated in the research relate the lack of motivation with: „, there should be a reward for pedagogues for additional work". It can be stated that motivation is very often identified as a question of salary. It is though that salary is the main stimulus for the teacher to work successfully. The informants emphasized the factors of negative motivation: ,, a significance of participation in preparing plans must be visible“, „, continuous change is exhausting”, ,an attitude that someone else has to do it is predominant “, ",passivity“, „, careless attitude to work". Therefore, a school leader's ability to ,explain the necessity of change to the pedagogues ", „introduce the members of the community with the problems in the organization" and ,leader's and teachers "reciprocal 
collaboration and work improvement". The experts also noted that in order for the changes in organization to be successful, planning and application of modern managerial principles is important: „clear goal”, ,strategic planning is important".

Analysing the information obtained during the interview, it was determined that informants distinguish aspects of work process organization. A very important factor of motivation is favourable work conditions: ,the schedule is constructed regarding the teacher's needs, ,, modern work tools”, ,environment that is secure and fit for work".

The experts name the lack of competencies as: „indifferent pedagogues “ attitude to school's work”, „not seeing beyond one's own problems and expectations", ,fear to make a mistake”, ,lack of confidence in expressing personal opinion”, ,incorrect interpretation of facts”, ,gap between the teachers and administration”, "lack of knowledge on education policy strategy".

When evaluating the leader's opportunities in motivating employees, it was ascertained that the leader's possibilities to motivate employees are limited, therefore, they evaluated these possibilities sceptically: „difficult, because the resources are insufficient”, „no one wants to work better for thanks”, „everything is influenced by the budget of the organization”, ,, there aren "t many motives to work good" etc.

The informants distinguished the following possibilities to motivate employees: "try to know your employees better", ,the teacher has to want to work in the school”, "psychological atmosphere in the organization is important”, ,importance of collaboration between colleagues”, ,trust and distribution of work”, ,, righteous and honest communication”.

\section{Conclusions}

It is important for the organizations to ascertain, what strivings influenced the employee to choose the organization, how he evaluates his work, assignments, what are his needs and what motivates him to accomplish work assignments better and what are his future plans in the organization. Having evaluated these aspects (choice of organization, residence and striving to remain in it), a motivation model should be created which is directed to the individual needs and strivings of every person.

The process of motivation in the management theory is explained as one of the most important processes taking place in the organization. It is the work motivating the individual to act in a desired direction, raising employee's satisfaction and considering the personal needs and strivings in an organization. The person's behaviour is affected by both internal and external means of motivation. However, it is admitted that internal motivation is more effective people seek to accomplish assignments even when there is no reward. 
Analysing the leaders' attitude to aspects of motivation, it was determined that: the school leaders do not have enough opportunities to apply various ways of employee motivation, which limits the motivation in schools to only these means of motivation: notice of effort, spoken commendation, note of acknowledgement. Creation of trust and collaboration environment in a school is especially related to the leader's personal characteristics and application of managerial skills. The teachers' motivation is diminished by these factors: often change of education programs, provisions of pedagogue attestation, insufficient pupil basket, reduced number of work hours, inappropriate microclimate in the school.

\section{References}

Armstrong, M. (2006). A handbook of human resource management practice. London: Philadelphia.

Atkinson, J. N., Feather, N. T. (1996). A theorie of achievement motivation. NewYork, Wiley. Aužbikavičienè, J. (2010). Pedagogu motyvacijos tobulinti kvalifikacija skatinimas mokykly vadovu patirties analizè. Šiauliai.

Barkauskaitè, M. (2001).Mokytojų kvalifikacijos kèlimas -nuolatinio mokymosi pagrindas. Pedagogika: mokslo darbai, 52 p. 63-67.

Baršauskienė, V., Almonaitienė, J., Lekavičienė, R., Antinienè, D. (2010). Žmoniu santykiai organizacijose. Kaunas: Technologija.

Blaskova, M., Gražulis, V. (2009). Motivation of human potential: theory and practice. Vilnius, Mykolas Romeris University.

Bowditch, J.L., Buono, A.F. (2001).A Primer on Organizational Bahavior. New York: Wiley.

Bučiūnienè, I. (1996). Personalo motyvavimas. Kaunas, Technologija.

Carolyn, C. (2004). What Motivates Staff? Family Practice Management. Downloaded from: http://www.aafp.org/fpm/2004/1100/p54.html. access (2015. 01. 03).

Coursey, D., Perry, J.L., Brudney, J., Littlepage, L. (2008). Psychometric verification of Perry's public service motivation instrument: Results for volunteer exemplars. Review of Public Personnel Administration, 28(1), p. 79-90.

Diržytė, A., Patapas, A., Mikelionytė, R. (2010). Viešojo ir privačiojo sektorių vadovų darbo motyvacijos ypatumai. Viešoji politika ir administravimas. Vilnius: Mykolo Romerio universitetas.

Felser, G. (2006). Motyvacijos būdai: asmens sèkme lemiantys faktoriai, praktinis psichologijos panaudojimas. Vilnius: Alma littera.

Franken, R.E. (2002). Human motivation. Belmont: Wadsworth//Thomson Learning.

Gražulis, V. (2005). Motyvacijos pasaulis - jo supratimo keliai ir klystkeliai. Vilnius: Ciklonas.

Gražulis, V., Valickas, A., Dačiulytė, R., Sudnickas, T. (2012). Darbuotojas organizacijos koordinačiu sistemoje: žmogiškojo potencialo vystymo perspektyvos. Vilnius: Mykolo Romerio universitetas.

Greenhaus, J. H., Callanan, G. A. (2010). Career management. SAGE Publications. Downloaded from: http://www.sagepub.com/greenhaus4e/study/chapters.htm.access (2015. 01. 15).

Herzberg, F. (1987). One More Time: how do you motivate employees? Harward Business Review 87. No. 5. 1987.

Higgins, E.T. \& Kruglanski, A.W. (Eds.). (2000). Motivational science: social and personality perspectives. Philadelphia: Psychology Press. 


\section{SOCIETY. INTEGRATION. EDUCATION. Volume II}

Houston, D.J. (2000). Public - Service motivation: A Multivariate test. Journal of Public Administration Research and Theoryp. 713-727.

Jadzauskaite, V. (2004). Darbuotojų motyvacija: kaip palengvinti pavaldinių kelionę akmenuotu keliu. Vadovo pasaulis. Nr. 4.

Kjeldsen, A. M. (2012). Dynamics of Public service motivation. Department of Political Science and Government. PhD Dissertation. Denmark: Aarhus University.

Lileikienè, T. (2008). Pedagoginių kompetencijų plètra Kauno miesto bendrojo lavinimo mokyklose. Downloaded from: https://ojs.kauko.lt/index.php/ssktpd/article/viewFile/ 66/60accesse (2014.11.26).

Lithuanian department of statistics. Downloaded from:http://www.stat.gov.lt.

Marcinkevičiūtė L. (2010). Darbuotojų motyvavimo modeliai: teoriniai ir praktiniai aspektai. Akademija, Kauno r.: Lietuvos žemès ūkio universiteto Leidybos centras.

Maslow, A.H .(1943). A theory of human motivation. Psychological Review.

Matuzienè, I., Tijūnaitienè, R., Petukienè, E. (2004). Darbo motyvacijos problematikos analizė žurnale „Vadovo pasaulis“. Ekonomika ir vadyba: aktualijos ir perspektyvos p. 184-189.

Mullins, L.J. (2004). Management and organisational behaviour. Harlow: Prentice-Hall.

Nutt P.C. (1999). Public - Private Differences and the Assessment of Alternatives for Decision Making. Journal of Public Administration Research and Theory. vol. 9, p.305349.

Pakalkaitè, L. (2006). Emocinis įsipareigojimas. Vadovo pasaulis.

Palidauskaite, J. (2007). Motyvacijos unikalumas valstybės tarnyboje. Viešoji politika ir administravimas. Nr. 19, p. 33-44 .

Palidauskaitė, J. ( 2008). Valstybès tarnautojų motyvavimas: lyginamasis aspektas. Viešoji politika ir administravimas. Nr. 25, p. 7-17.

Re'em, Y. (2011). Motivating public sector employees: an application-oriented analysis of posibilities and pactical tools. Working papers. Hertie school of governance. Downloaded from: http:/www.hertie-school.org/fileadmin/images/Downloads/ working_papers/60.pdf.

Access (2014. 10.11).

Redman, T., Wilkinson, A. (2009). Contemporary human resource management text and cases. Financial times Prentice Hall. Harlow, England.

Rodzevičiūtè, E. (2007).Pedagogu profesijos pasirinkimo motyvacija ir jos kaita studiju metu. Vilnius: VPU.

Sims, S.J., Sims, R.R. (2007). Human resource management - Contemporary Issues, Challenges, and Opportunities. United States: Information Age Publishing.

Statistikos departamento prie Lietuvos Respublikos Vyriausybès svetaine: Mokytoju skaičiaus kitimas Lietuvos mokyklose. Downloaded from http://db1.stat.gov.lt/statbank/ SelectVarVal/saveselections.asp.access (2015.01.04).

Užkurèlienė, J. (2006). Kaip motyvuoti personalą krizès sąlygomis? Vadovo pasaulis. Nr. 11

Taylor, F. W. (2005). Moksliniai valdymo principai. Vilnius: Eugrimas.

Tosi, H.L, Mero, N.P. (2003). The Fundamentals of Organizational Behaviour What Managers Need to Know. Blackwell publishing.

Žaptorius, J. (2007). Darbuotojų motyvavimo sistemos kūrimas ir jos teorinè analizè. Filosofija. Sociologija. Vilnius: LMA .T.18. Nr.4. 